Cahiers $d u$ MONDE RUSSE

\section{Cahiers du monde russe}

Russie - Empire russe - Union soviétique et États indépendants

61/3-4 | 2020

Écritures visuelles, sonores et textuelles de la justice

\title{
OFFORD Derek, RJEOUTSKI Vladislav, ARGENT Gesine, The French Language in Russia. A Social, Political, Cultural, and Literary History
}

\section{Gary Marker}

\section{(2) OpenEdition}

Electronic version

URL: https://journals.openedition.org/monderusse/12099

DOI: 10.4000/monderusse. 12099

ISSN: 1777-5388

\section{Publisher}

Éditions de l'EHESS

Printed version

Date of publication: 1 July 2020

Number of pages: $514-517$

ISBN: 978-2-7132-2832-2

ISSN: $1252-6576$

\section{Electronic reference}

Gary Marker, "OFFORD Derek, RJEOUTSKI Vladislav, ARGENT Gesine, The French Language in Russia. A Social, Political, Cultural, and Literary History", Cahiers du monde russe [Online], 61/3-4 | 2020, Online since 01 July 2020, connection on 14 September 2022. URL: http://journals.openedition.org/ monderusse/12099; DOI: https://doi.org/10.4000/monderusse.12099 
OFFORD Derek, RJEOUTSKI Vladislav, ARGENT Gesine,

\section{The French Language in Russia}

\section{A Social, Political, Cultural, and Literary History}

Amsterdam : Amsterdam University Press, 2018, 699 p.

This massive volume constitutes an exhaustive, multi-thematic, intensively researched, and richly informative study of the use and place of French in eighteenth- and nineteenth century Russia. It has already received several well-deserved positive reviews and award (The 2019 Marc Raeff Prize from the Eighteenth-Century Russian Studies Association). The title deems it a social, political, cultural and literary history, and the volume follows through on all points. Although multiauthored, the narratives read as if composed by a single hand, no simple feat for a work as long as this one (nearly 700 pages).

The authors have done an excellent job of presenting the panoply of material in discrete sections, "Teaching and Learning French," "French at Court" "Writing French", "Language Attitudes", etc. each of which is organized chronologically. It is at once encyclopedic and relentless in deploying empirical research - their own and others' - to interrogate all manner of received wisdoms, whether they be high theory, narrative topoi, or out-and-out cliches about French, bilingualism, and the Russian nobility, most of which will be familiar to readers of this journal. They adopt a mode of rigorous hypothesis testing, first reciting conventional wisdom (they prefer "grand narratives"), and then interrogating it against the backdrop of evidence. Some they accept in toto, others they reject, most they complicate. All of this is clearly laid out in the introduction, and it then continually reprised in the subsequent chapters. So, have no doubt, chers lecteurs, The French Language in Russia is an important piece of scholarship.

The chronological arc presented here generally conforms to the accepted trajectory: relatively uncommon through the first decades of the eighteenth century, by mid-century French was rapidly emerging as the second language of choice among the upper nobility, deemed essential to the project of cultural Europeanization, as it was in much of the rest of Europe. Once so ensconced, it maintained that status for over a century, and still bore cultural capital more-or-less until the revolution of 1917. The authors are insistent — correctly so in my view - that this long love affair with French should not be construed as slavish imitation, as in the mocking of "Voltairianism" in some satirical journals, any more than it would be in other parts of Europe that partook of lingua franca. Indeed, they are harshly critical of this idea, and in several points within the text they emphasize the creative and nuanced ways in which Russia's Francophones inscribed their own codes and meanings, specific to a Russian milieu. They are equally insistent that bilingualism was not and should not be interpreted as some sort of compromise with national identity. Quite the contrary, "the achievement of some new synthesis of cultural leanings and linguistic competencies may even produce a strong sense of self...a productive outcome of Russia's engagement with the world beyond its western borders." (p. 588) 
The authors have effectively mined a wide extensive corpus of conceptual works, from Semiotics, literary theory, and Sociolinguistics. Much, not surprisingly, comes out of Russian studies, in particular the Moscow-Tartu semiotics of Iurii Lotman, and Viktor Zhivov. Their adaptations of semiotic "dual models" are simultaneously broad and judicious, endorsing its overarching approach and insights (the nation as a constructed cultural entity, French as a performative identity, the ambiguous binary of literature and "reality", etc.) while at the same time parting company with it on a number of specific points. In this context let us note their frequent references to and endorsement of Michelle Marrese's writings (e.g., p. 251-252), most notably her revisionary essay "The Poetics of Everyday Behavior' Revisited," which conclusively demonstrated inter alia that, contrary to stereotypes, the vast majority of Francophone Russians did indeed know, speak, and write in Russian. ${ }^{1}$ The engagement with cultural and sociolinguistic theory outside of Russistika is also extensive, however, and the authors have effectively deployed multiple insights, including the notions of linguistic codes, bilingualism vs. diglossia, and orality vs. written text. They approach all of them in a salutary spirit of learned and cautious instrumentality, that is they look to theory in order to elucidate or clarify specific phenomena rather than as over-arching paradigms.

The French Language in Russia raises far more topics than can be noted even in a long review such as this one. Here I shall simply identify those that particularly caught my attention. Much of the book focuses on the intersection of French usage and the twists and turns of national consciousness, a fundamental aspect of what might be termed Russia's long and tormented turn toward Europe. The well-known contretemps between Admiral Shishkov and Karamzin over language "contamination" is explored in detail, and with a keen eye for ambiguities, even if Shishkov still comes off as a rather closed-minded purist. I particularly liked the discussion of Slavophilism and its paradoxes, such as the fact that leading Slavophiles were comfortable with French, and some, such as Ivan Kireevskii, sometimes wrote in French. Similarly, the section on nineteenth-century writers (Dostoevskii, Turgenev, Tolstoi) interrogates their novels as sites where language and national identity intertwined was very engaging, rather reminiscent in tone and approach of William Todds' 1986 study, Fiction and Society in the Age of Pushkin. (A small question in this context: did Russian Schellingianism have any bearing on such discourses, in particular at Moscow University where Naturphilosophie had a considerable presence in the first three of decades of the nineteenth century, and later among leading representatives of Official Nationality and Slavophilism as well as Dostoevskii? ${ }^{2}$ ).

The book also analyzes the presence of several European languages other than French within Russia's educated lay society, especially German and Latin. Both languages, they confirm, were employed widely in the correspondences of the Academy of Sciences and in diplomatic correspondence. Both languages carried a degree of cultural capital within aristocratic circles, particularly in the eighteenth century, but neither came to rival French in that regard. In this context let me express a wee-small regret that they did not say more about foreign language use 
among seminarians and educated clergy. They do take note of it, and, as the citations show, they are very much up-to-date on the current research by Ekaterina Kislova and others about seminary language curricula in the eighteenth century and the consequent clerical bi-and even polylingualism that quite a few leading clergy embraced, for example the luminaries who engaged in the intellectual/cosmopolitan beau monde of the major cities and who participated in what is sometimes termed the "Orthodox Enlightenment". I for one would be interested to learn whether any leading clerics (Filaret Drozdov comes immediately to mind) had a specifically clerical or confessional understanding of Francophonie.

Not surprisingly, when one reads a work so multi-dimensional as this, thoughts inevitably percolate in one's mind about where next this line of research might go. A few possibilities: first, regarding the social or socio-cultural dimensions, the work leaves no doubt that, true to conventional wisdom, Francophonie was restricted almost entirely to the nobility, and for most of the two centuries a small subset at that. It remains a source of wonder, then, that it has loomed so large and so long in the collective caricatures of Russian educated culture. Why, we might ask, does it endure in the imaginations of others? What does it suggest about the ways in which overarching "imagined communities" persist when empirical research conclusively reveals something far more complicated (and far more interesting!).

Similarly, the authors note that French was often the domestic language of aristocratic families both in the capital and on the estates. How, then, did the much larger cohorts who stood outside this slice of the noble soslovie - chinovniki, other nobles, household servants, tradesmen, etc.- but who nevertheless bore regular witness to spoken French through interactions with Francophone nobles perceive its cultural or social meaning? Are there sources that might reveal whether the nuances and variable practices, so carefully elaborated here, were visible to them? If so, what did they make of them? More generally, what did they take speaking in French to signify, other than as a mark of aristocratic exceptionalism? One thinks of works such as Priscilla Roosevelt on noble estates (used here to very good effect) and Richard Stites', Serfdom, Slavery, and the Arts as places where one might look for these cross-estate interactions.

For a domain like the Russian Empire, in which so many of the sovereign's subjects were officially marked as "other" (inorodtsy, inozemtsy, inovertsy, iasachnye...) it would be interesting to learn more about Francophonie in the broader imperial context. The authors provide an engaging analysis of French among certain Baltic - largely German - elites. But is there anything to be said about the other peoples? As the authors show, nationalism and national consciousness transformed language choice into a badge of identity politics, and this phenomenon extended to elites elsewhere in the Empire, in particular Poland, Ukraine, and Crimea. Did Francophonie enter into the political mix there as well (one assumes so at least for Polish szlachta) and, if so, how? Did they perhaps embrace French as a badge of their own "Europeanness," or even "non-Russianness"?

On a related note, I wondered about the intersection of Francophonie and confessional identity. By the 1830s there existed bilingual Francophone Russian 
émigré communities and noteworthy individuals such as Sofia Svechina and the Russian Catholic community in Paris. ${ }^{3}$ As converts from Orthodoxy they were anathema, but they continued to correspond with people in Russia, both Catholics and Orthodox, and in both French and Russian. How might the practices of émigré communities such as these factor into their ideas of vibrant language exchange and mediation?

A final query relates to gender. Building upon an ever-growing body of scholarship, (Michelle Marrese, Catriona Kelly, Elena Gretchanaia, Alessandra Tosi, among others) the volume offers several discussions of women's diaries, personal letters, and novels, salons, and other topics. Each provide useful and thought-provoking reflections on the place of French in women's writing, and when taken in toto they constitute a considerable body of commentary. How might one achieve this "in toto"? It would be helpful, I think, to bring these separate pieces together at some point and thereby open up them to an overall gendered analysis. Ask, for example, whether Francophone Russian women writers constructed gender differently in the two languages, consciously or otherwise. In a similar vein, might gender offer insights into textualized masculinities, in both men's and women's writings, and would these too vary between French vs. Russian? One suspects so, given what we now know about salons, lodges, and noble family chapbooks, so this might well be a productive avenue for future research.

Let me end this review with some thoughts about readership. This is a long and densely detailed book, directed primarily at specialists, of which there are multiple likely cohorts. Russianists, of course, will find much of value in it, particularly those working in the literary, intellectual, and cultural history of early-modern and modern Russia. So too should non-Russianists working in similar thematic and comparative areas, in particular those interested in practices and performances of bilingualism. Many scholars, I suspect, will consult the work for its particulars as a reference, which it surely is, rather than read it in full. That would be a pity, since this is much more than a collection of empirical gems vignettes. While it does not put forth a unifying bold hypothesis or overarching interpretive schema (and therein lies its real strength), it does provide a well-conceived and unified narrative trajectory which deserves to be savored as a whole. Might the authors consider crafting an abbreviated version at some future date and thereby capture a broader readership? Just a thought.

1 - Michelle Marrese, “'The Poetics of Everyday Behavior' Revisited: Lotman, Gender, and the Evolution of Russian Noble Identity," Kritika, 11, 4 (2010): 701-739.

2 - Vsevolod Setchkarev, Schellings Einfluss in der russischen Literatur der 20er und 30er Jahre des XIX. Jahrhunderts. Leipzig. 1939.

3 - Tatyana V. Bakhmetyeva, Mother of the Church: Sofia Svechina, the Salon, and the Politics of Catholicism in Nineteenth-Century Russia and France (Northern Illinois, 2016).

\section{Gary Marker}

